\title{
STUDI KONSENTRASI BUBUR BUAH NIPAH (Nypa fruticans wurmb) DAN RUMPUT LAUT (Euchema cottonii) YANG TEPAT TERHADAP PERMEN JELLY YANG DIHASILKAN
}

\author{
Dian Sriwahyuni ${ }^{(1)}$, dan Hermiza Mardesci, S.TP., MP(2) \\ (1) Alumni Teknologi Pangan Faperta UNISI \\ ${ }^{(2)}$ Dosen Teknologi Pangan Faperta UNISI
}

\begin{abstract}
Abstrak
Nipah (Nypa fruticans wurmb) adalah salah satu pohon anggota familly palem (Arecaceae) yang umumnya tumbuh di daerah rawa yang berair payau atau daerah pasang surut di dekat pantai. Bagian dalam buah berwarna bening agak putih tergantung kemasakan buah. Buah nipah yang muda teksturnya lembek, berwarna bening sedikit keruh pada bagian dalamnya dan berwarna putih seperti kelapa jika sudah tua. Rumput laut merupakan salah satu komoditi perikanan indonesia yang cukup potensial sebagai penghasil devisa negara. Kadar karagenan setiap Euchema berkisar antara 54-73\% tergantung pada jenis dan tempat tumbuhnya. Permen jelly merupakan permen yang bahan utamanya dari air, sari buah serta bahan tambahan lain yang dapat membentuk gel, yang berpenampilan jernih transparan serta mempunyai tekstur dengan kekenyalan tertentu. Tujuan dari penelitian ini adalah untuk mengetahui konsentrasi bubur buah nipah (Nypa fruticans wurmb) dan rumput laut (Euchema cottonii) yang tepat terhadap mutu permen jelly. Penelitian telah dilakukan dengan rancangan acak lengkap (RAL), hasil penelitian permen jelly buah nipah dan rumput laut bahwa perakuan terbaik terdapat pada perlakuan D (75\% buah nipah : 25\% rumput laut) dengan skor kadar air 22,00\%, kadar gula reduksi 64,66\%, kadar pati $22,00 \%$ dan penilaian organoleptik rasa $3,90 \%$, warna $4,20 \%$, aroma $3,50 \%$, tekstur $3,85 \%$.
\end{abstract}

Kata Kunci : Permen Jelly, Buah Nipah, Rumput Laut

\section{PENDAHULUAN}

Kabupaten Indragiri Hilir memiliki luas areal perkebunan nipah sebesar 12,807 Hektar dan produksi nipah ratarata per Ha 5.981 (Badan Pusat Statistik, 2015). Nipah atau (Nypa fruticans wurmb) adalah salah satu pohon anggota familly palem (Arecaceae) yang umumnya tumbuh di daerah rawa yang berair payau atau daerah pasang surut di dekat pantai. Pohon nipah (Nypa fruticans wurmb) tumbuh di lingkungan hutan bakau dan dapat dijadikan sebagai sumber alternatif pengobatan tradisional, karena didalam buah nipah banyak mengandung antioksidan yang tinggi selain itu nipah juga merupakan sumber pangan dan energi.

Buah nipah yang muda (Nypa fruticans wurmb) yang muda dagingnya lunak, berwarna putih bening, kempal seperti jelly dan mempunyai rasa yang sedikit manis. Hasil analisa daging buah nipah dengan tingkat kematangan muda yaitu kadar air 38,96 \%; kadar abu 0,98 $\%$; kadar lemak 0,70 \%; kadar protein 2,95 \%; kadar karbohidrat 56,41 \%; total 
gula 27,22\%; vitamin C $0,60 \%$ (Subiandono et al., 2011).

Buah nipah merupakan buah musiman yang berbuah 2 kali dalam setahun, maka untuk dapat menikmati buah nipah setiap saat dan memperpanjang masa simpannya adalah dengan cara mengolahnya menjadi permen jelly.

Permen jelly merupakan permen yang dibuat dari air atau sari buah dan bahan pembentuk gel yang berpenampakan jernih, transparan serta mempunyai tekstur dengan kekenyalan tertentu. Permen jelly sangat digemari karena teksturnya yang khas bersifat elastis. Permen jelly telah banyak dibuat oleh beberapa industri dimana pada umumnya terbuat dari gelatin dan karagenan. Gelatin merupakan suatu produk yang diperoleh dari hidrolisis persial kologen yang berasal dari jaringan ikat dan tulang hewan yang berfungsi sebagai pembentuk gel, pelapis dan pengental. Sedangkan karagenan terbuat dari tumbuh-tumbuhan yaitu rumput laut. Pada penelitian ini rumput laut digunakan dalam pengolahan permen jelly buah nipah karena lebih mudah diperoleh dibandingkan dengan gelatin.

Rumput laut (Euchema cottoni) merupakan salah satu komoditi kelautan indonesia yang cukup potensial sebagai penghasil devisa negara. Karagenan dalam setiap eucheuma berkisar antara 54-73\% tergantung pada jenis dan tempat tumbuhnya. Budidaya rumput laut ini di Indonesia antara lain : Lombok, Sumbar, Sulawesi Tenggara, Sulawesi Tengah, Lampung, Kepulauan Seribu, dan perairan Pelabuhan Ratu. Rumput laut bertujuan untuk membantu tekstur pada permen jelly buah nipah, karena rumput laut dapat menambah tekstur kenyal pada permen jelly.

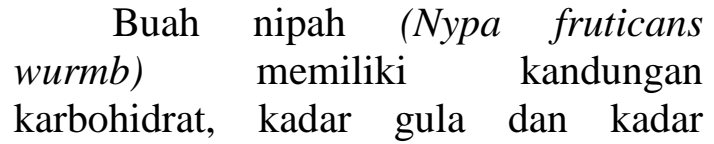
protein cukup baik berpotensi untuk pengganti makanan pokok (beras, jagung, sagu). Melihat dari kandungan buah nipah yang cukup baik, maka dapat dikombinasikan dengan rumput laut untuk diolah menjadi produk yang disukai oleh semua golongan (dewasa/anak-anak) yaitu permen jelly.

Selama ini buah nipah di Indragiri Hilir hanya diolah menjadi nata dan manisan, namun kurang disukai oleh banyak golongan (anak-anak/dewasa). Solusinya adalah dengan mengolah buah nipah menjadi permen jelly. Salah satu cara untuk membuat permen jelly buah nipah tersebut terasa nikmat yaitu dengan menyeimbangkan komposisi bahan. Oleh karena itu diperlukan penelitian untuk mengetahui persentase bahan yang tepat pada pengolahan permen jelly buah nipah.

Dari penelitian pendahuluan yang dilakukan bahan perbandingan antara 125 gram bubur buah nipah dan 125 gram bubur rumput laut dengan penambahan gula 250 gram, menghasilkan permen jelly dengan rasa manis dan warna putih keruh. Permasalahan utama dalam pembuatan permen jelly buah nipah ini adalah belum diketahui konsentrasi bubur yang tepat untuk menghasilkan permen jelly yang memenuhi standar mutu. Dengan demikian penulis tertarik melakukan penelitian yang berjudul "Studi Konsentrasi Bubur Buah Nipah (Nypa fruticans wurmb) dan Rumput Laut (Euchema cottonii) yang Tepat terhadap Permen Jelly yang Dihasilkan".

\section{Tujuan Penelitian}

Tujuan dari penelitian ini adalah untuk mengetahui konsentrasi bubur buah nipah yang tepat pada pengolahan 
permen jelly buah nipah (Nypa fruticans wurmb) dan rumput laut (Euchema cottonii) serta menambah nilai ekonomis buah nipah (Nypa fruticans wurmb)

\section{Manfaat Penelitian}

Manfaat dari penelitian ini adalah untuk memberikan pengetahuan kepada masyarakat mengenai manfaat dari buah nipah serta memberikan alternatif kepada masyarakat untuk mengolah buah nipah menjadi suatu produk yang bermanfaat dan bernilai jual lebih tinggi seperti permen jelly buah nipah dan rumput laut.

\section{METODOLOGI PENELITIAN}

\section{Bahan}

Bahan yang digunakan pada penelitian ini adalah buah nipah yang muda, rumput laut, air, gula pasir/sukrosa, air kapur dan bahan yang digunakan untuk analisis kimia adalah : aquades, Pb-asetat, Na-Oksalat, $\mathrm{Na}-$ hidrat, larutan luffschool KI, $\mathrm{H}_{2} \mathrm{SO}_{4}, \mathrm{Na}$ Thiosulfat, aquades , asetat, $\mathrm{Na}_{2} \mathrm{CO}_{3}, \mathrm{I} 2$, $\mathrm{K}_{2} \mathrm{SO}_{4}$, CuSO4-5H2O, metal red, metilen blue, alkohol, indikator mengsel, $\mathrm{NaOH}$.

\section{Alat}

Alat yang digunakan dalam penelitian ini adalah panci, pisau, telenan kompor, blender, baskom, mangkok, gelas ukur, adapun alat untuk analisa kimia yaitu: timbangan, labu takar, erlenmenyer, dan incubator, cawan porselen, oven, desikator, timbangan, kjeldahl, labu suling, indikator mengsel, gelas piala, batu didih, cawan.

\section{Metode Penelitian}

Penentuan penelitian pada permen jelly menggunakan perbandingan bahan dengan konsentrasi gula yang digunakan 250 gram.

$\mathrm{A}=$ buah nipah $0 \%$ : rumput laut $100 \%$

$\mathrm{B}=$ buah nipah $25 \%$ : rumput laut $75 \%$

$\mathrm{C}=$ buah nipah $50 \%$ : rumput laut $50 \%$

$\mathrm{D}=$ buah nipah $75 \%$ : rumput laut $25 \%$

Perencanaan percobaan yang dilakukan pada penelitian ini adalah rancangan acak lengkap dengan 4 perlakuan dan 3 ulangan sehingga diperoleh pola perlakuan 4X3 dengan 12 unit percobaan

\section{Pelaksanaan Penelitian}

\section{Proses pembuatan bubur buah nipah} (Nypa fruticans wurmb)

Dalam pembuatan bubur buah nipah yaitu terdiri dari beberapa tahapan yaitu, sortasi, pembelahan buah, pencucian dan penggilingan. Buah nipah yang diambil dalam penelitian ini adalah buah nipah muda.

\section{Sortasi}

Sortasi adalah pemisahan bahan baku yang masih dalam kondisi bagus dengan bahan baku yang cacat.

2. Pembelahan buah

Pembelahan buah bertujuan untuk memudahkan mengambil daging buah.

3. Pencucian

Buah yang telah diambil di cuci dengan air bersih untuk menghilangkan kotoran yang menempel.

4. Penggilingan

Setelah pencucian kemudian dilakukan penggilingan dengan menggunakan blender guna untuk membuat bubur buah nipah ditambahkan air $50 \mathrm{ml}$. 
Proses pembuatan bubur rumput laut (Eucheuma cottoni) beracuan pada (Hambali et, al, 2004) yang telah dimodifikasi.

Dalam pembuatan bubur rumput laut terdiri dari beberapa tahap proses yaitu: sortasi, pencucian, perendaman, pencucian, dan penggilingan.

1. Sortasi

Sortasi adalah pemisahan antara bahan baku yang masih dalam kondisi bagus dan yang cacat. Sortasi bertujuan untuk memilih rumput laut yang berkualitas baik.

2. Pencucian

Setelah dilakukan sortasi maka selanjutnya dilakukan pencucian rumput laut yang akan digunakan dengan bersih.

3. Perendaman

Rumput laut kering direndam selama 15 jam menggunakan air kapur $(\mathrm{CaCO} 3)$ dengan konsentrasi 0,4\%.

4. Pencucian

Setelah dilakukan perendaman, maka selanjutnya rumput laut dicuci dengan bersih.

5. Penggilingan/penghalusan.

Setelah rumput laut telah dicuci maka selanjutnya dilakukan proses penggilingan/penghalusan dengan blender ditambahkan air $50 \mathrm{ml}$ agar memudahkan dalam proses penggilingan/penghalusan.

Prosedur pembuatan permen jelly buah nipah (Nypa fruticans wurmb) beracuan Hambali et al., 2004 yang telah dimodifikasi.

Prosedur pembuatan permen jelly buah nipah dan rumput laut:

\section{Pencampuran}

Pecampuran dilakukan dengan cara memasukkan bubur buah nipah kedalam campuran bubur rumput laut. Gula yang digunakan pada setiap perlakuan yaitu 250 gram.

2. Pemasakan

Bubur rumput laut, bubur buah nipah, gula yang telah dicampur dimasak, kemudian diaduk hingga mengental selama 20 menit dengan suhu $70^{\circ} \mathrm{C}$.

3. Pencetakan

Larutan yang telah masak kemudian dimasukkan kedalam cetakan.

4. Pendinganan

Permen jelly yang telah dicetak kemudian didinginkan selama 1 jam dengan suhu ruang $27-32^{\circ} \mathrm{C}$.

5. Pemotongan

Pemotongan permen jelly dengan ukuran $1.5 \mathrm{~cm}$.

6. Pengeringan

Permen jelly dikeringkan dibawah sinar matahari selama 5 hari dengan waktu 7 jam.

7. Pengemasan

Selanjutnya permen jelly tersebut di kemas ke dalam gelas plastik agar tetap hygenis.

\section{Parameter Pengamatan}

Adapun pengamatan yang dilakukan pada penelitian ini adalah uji kadar air, uji gula reduksi, kadar pati, dan uji organoleptik.

\section{HASIL DAN PEMBAHASAN}

\section{Kadar Air}

Analisa kadar air pada permen jelly dilakukan untuk mengetahui jumlah persentase kadar air yang terdapat pada permen jelly buah nipah dan rumput laut. Dari hasil analisa kadar air ini diketahui bahwa $F_{\text {hitung }}>F_{\text {tabel. }}$. Sehingga harus dilakukan uji lanjut BNT. Hasil rata-rata kadar air dapat dilihat pada tabel 1 . 
Tabel 1. Analisa Kadar Air terhadap Permen jelly Buah Nipah

\begin{tabular}{|l|c|}
\hline \multicolumn{1}{|c|}{ Perlakuan } & \multicolumn{2}{c|}{ Rata-rata (\%) } \\
\hline $\mathrm{D}=75 \%$ buah nipah $: 25 \%$ rumput laut & $22,00 \quad \mathrm{a}$ \\
\hline $\mathrm{C}=50 \%$ buah nipah $: 50 \%$ rumput laut & $22,33 \quad$ a b \\
\hline $\mathrm{B}=25 \%$ buah nipah $:$ 75\% rumput laut & $22,66 \quad \mathrm{~b}$ \\
\hline $\mathrm{A}=0 \%$ buah nipah $: 100 \%$ rumput laut & $23,66 \quad \mathrm{~b}$ \\
\hline
\end{tabular}

Keterangan: angka-angka pada jalur yang sama diikuti oleh huruf kecil yang sama menunjukkan berbeda sangat tidak nyata menurut Uji Beda Nyata Terkecil pada taraf 5\%

Pada tabel 1 kadar air tertinggi diperoleh dari perlakuan A $(0 \%$ buah nipah : 100\% rumput laut) dengan skor $23,66 \%$ dan kadar air terendah diperoleh dari perlakuan D (75\% buah nipah : $25 \%$ rumput laut) dengan skor $22,00 \%$. Semakin banyak jumlah rumput laut yang ditambahkan maka akan semakin tinggi jumlah kadar air yang ada pada permen jelly. Hal ini karena rumput laut mengandung karagenan. Di mana karagenan ini mempunyai sifat mudah larut dalam air dan mampu mengikat air sehingga kadar air yang terikat dalam disperse koloid karagenan umumnya sangat sulit keluar sebagai air bebas
(Basuki et al. 2014). Hal ini didukung oleh (Winarno, 1990) karagenan mempunyai sifat mudah larut dalam air dan mampu menyerap air.

\section{Kadar Gula Reduksi}

Analisa kadar gula reduksi pada permen jelly dilakukan untuk mengetahui jumlah kandungan kadar gula sukrosa yang terdapat pada permen jelly buah nipah dan rumput laut. Dari hasil analisa kadar gula ini diketahui bahwa $F_{\text {hitung }}>F_{\text {tabel. }}$. Sehingga harus dilakukan uji lanjut BNT. Hasil rata-rata kadar air dapat dilihat pada tabel 2.

\section{Tabel 2. Analisa Kadar Gula Reduksi terhadap Permen Jelly Buah Nipah}

\begin{tabular}{|l|c|}
\hline \multicolumn{1}{|c|}{ Perlakuan } & Kadar Gula Reduksi \\
\hline $\mathrm{A}=0 \%$ Buah nipah : 100\% Rumput laut & $62,00 \mathrm{a}$ \\
\hline $\mathrm{B}=25 \%$ Buah nipah : 75\% Rumput laut & $64,00 \mathrm{a}$ \\
\hline $\mathrm{D}=75 \%$ Buah nipah : 25\% Rumput laut & $64,66 \mathrm{a}$ \\
\hline $\mathrm{C}=50 \%$ Buah nipah : 50\% Rumput laut & $65,00 \quad \mathrm{~b}$ \\
\hline
\end{tabular}

Keterangan: angka-angka pada jalur yang sama diikuti oleh huruf kecil yang sama menunjukkan berbeda tidak nyata menurut Uji Beda Nyata Terkecil pada taraf 5\%

Dari tabel 2 kandungan kadar gula reduksi yang tinggi terdapat pada perlakuan C (50\% Buah nipah : 50\% rumput laut) dengan skor $65,00 \%$ dan kadar gula yang rendah terdapat pada perlakuan A (0\% Buah nipah : $100 \%$ Rumput laut) dengan skor $62,00 \%$.

Tingginya kadar gula reduksi pada perlakuan C $(50 \%$ Buah nipah : 50\% rumput laut) disebabkan karena kurangnya kandungan konsentrasi penambahan ekstrak rumput laut sehingga kadar gula reduksi pada produk permen jelly $\mathrm{C}$ sebesar $65,00 \%$. Hal ini sesuai dengan Santoso (2010), faktor yang dapat mempengaruhi hasil permen jelly antara lain : pemilihan bahan, pemilihan gula, penggunaan pengenyal, pemasakan, dan pendinginan. 
Dalam perlakuan A (buah nipah $0 \%$ dan rumput laut $100 \%$ ) dengan skor $62,00 \%$ dapat dilihat bahwa terjadi penurunan kadar gula reduksi seiring dengan semakin tingginya konsentrasi penambahan ekstrak rumput laut. Hal ini disebabkan karena serat yang terkandung pada rumput laut dapat mengikat sukrosa, pernyataan ini sesuai dengan pendapat Novelina, dkk (2014) bahwa semakin banyaknya penambahan ekstrak rumput laut, maka serat-serat pangan yang terkandung pada rumput laut semakin banyak mengikat sukrosa dan menyebabkan ketersediaan gula pada permen jelly menjadi berkurang. Menurut SNI (2008) untuk kadar gula reduksi yang terkandung dalam permen jelly buah nipah dan rumput laut adalah maksimum 25\%. Hasil pengujian menunjukkan bahwa formulasi tidak memberikan pengaruh nyata terhadap kadar gula permen jelly, hal ini disebabkan jumlah gula yang ditambahkan sama di setiap perlakuan.

\section{Kadar Pati}

Analisa kadar pati pada permen jelly dilakukan untuk mengetahui jumlah kandungan kadar pati yang terdapat pada permen jelly buah nipah. Dari hasil analisa kadar pati ini diketahui bahwa $\mathrm{F}_{\text {tabel }}>\mathrm{F}_{\text {hitung. }}$ Sehingga harus dilakukan uji lanjut BNT. Hasil rata-rata kadar karbohidrat dapat dilihat pada tabel 3.

Tabel 3. Analisa Kadar Pati terhadap Permen Jelly Buah Nipah

\begin{tabular}{|l|cc|}
\hline \multicolumn{1}{|c|}{ Perlakuan } & \multicolumn{2}{|c|}{ Kadar Pati (\%) } \\
\hline $\mathrm{A}=0 \%$ buah nipah : $100 \%$ rumput laut & 16,66 & $\mathrm{~A}$ \\
\hline $\mathrm{B}=25 \%$ buah nipah $: 75 \%$ rumput laut & 18,66 & $\mathrm{~A}$ B \\
\hline $\mathrm{C}=50 \%$ buah nipah $: 50 \%$ rumput laut & 21,00 & $\mathrm{~B}$ C \\
\hline $\mathrm{D}=75 \%$ buah nipah $: 25 \%$ rumput laut & 22,00 & $\mathrm{C}$ \\
\hline
\end{tabular}

Keterangan: angka-angka pada jalur yang sama diikuti oleh huruf kecil yang sama menunjukkan berbeda sangat tidak nyata menurut Uji Beda Nyata Terkecil pada taraf 5\%

Dari tabel 3 kandungan kadar Pati tertinggi terdapat pada perlakuan D ( $75 \%$ buah nipah : $25 \%$ rumput laut) dan kadar gula yang rendah terdapat pada perlakuan A (0\% buah nipah : $100 \%$ rumput laut). Tingginya kadar pati pada perlakuan D sebesar 22,00\% disebabkan bahwa semakin banyak kandungan buah nipah maka kadar patinya akan semakin tinggi. Hal ini sesuai dengan kandungan kadar pati dalam buah nipah yaitu 56,41\% (Endro Subandriono, 2010). Dalam perlakuan A dapat dilihat bahwa terjadinya penurunan kadar pati. Hal ini disebabkan karena adanya interaksi antara pati, gula dan proses pemanasan.

\section{Penilaian Organoleptik}

Penilaian organoleptik dengan menggunakan uji hedonik pada permen jelly buah nipah dan rumput laut terhadap warna, aroma, rasa dan tekstur. uji hedonik merupakan salah satu jenis uji penerimaan. dalam uji ini panelis diminta mengungkapkan tanggapannya tentang kesukaan atau sebaliknya. disamping itu mereka juga mengemukakan tingkat kesukaan atau ketidaksukaan (Rahayu., et al 2001).

\section{Rasa}

Rasa berbeda dengan bau dan lebih banyak melibatkan panca indera lidah. Rasa sangat sulit dimengerti secara tuntas oleh karena selera manusia sangat 
beragam. Umumnya makanan tidak hanya terdiri dari suatu kelompok rasa saja. Tetapi merupakan gabungan dari berbagai rasa yang terpadu sehingga menimbulkan rasa makanan yang enak. Rasa merupakan faktor yang mempengaruhi penerimaan seorang terhadap suatu makanan. Rasa secara umum dapat dibedakan menjadi asin, manis, pahit dan asam (Winarno, 2002).

Rasa yang paling banyak disukai yaitu pada perlakuan B (25\% buah nipah : $75 \%$ rumput laut) dengan skor $4,100 \%$ sedangkan yang kurang disukai yaitu pada perlakuan A $(0 \%$ buah nipah : $100 \%$ rumput laut) dengan skor 3,850\%. Hasil penelitian yang dilakukan oleh Santoso (2007) menujukkan bahwa perlakuan yang ditambahkan rumput laut paling sedikit, lebih disukai rasanya oleh panelis dibandingkan dengan permen jelly yang banyak ditambahkan rumput laut. Hal ini diduga karena penambahan rumput laut yang banyak menyebabkan adanya rasa khas dari rumput laut yang kuat pada permen jelly yang tidak disukai oleh panelis.

\section{Warna}

Warna merupakan salah satu apek penting dalam hal penerimaan konsumen terhadap suatu produk pangan. Warna dalam bahan pangan dapat menjadi ukuran terhadap mutu, warna juga dapat digunakan sebagai indikator kesegaran atau kematangan (Winarno, 1992).

Warna yang paling disukai pada perlakuan D (75\% buah nipah : $25 \%$ rumput laut) dengan skor $4,20 \%$ dan yang kurang disukai pada perlakuan A (25\% buah nipah : $75 \%$ rumput laut) dengan skor 3,90\%. Hal ini menunjukkan bahwa kesukaan panelis terhadap parameter organoleptik warna cenderung meningkat dengan semakin banyak penambahan buah nipah dan semakin sedikit penambahan rumput laut. Hal ini disebabkan karena panelis lebih menyukai warna putih dikarenakan penambahan buah nipah lebih banyak dibandingkan dengan rumput laut.

Hasil penelitian ini sejalan dengan penelitian yang dilakukan oleh Santoso 2007, dimana semakin banyak rumput laut maka akan menyebabkan warna menjadi keruh.warna khas dari kappakaragenan berwarna agak gelap dan mempunyai tekstur yang mudah retak dibandingkan iota-karagenan (Fardiaz, 1989).

\section{Aroma}

Aroma dari suatu produk juga merupakan salah satu hal yang sangat penting untuk menarik minat konsumen dimana produk dapat disukai dan diterima masyarakat umum.

Aroma yang paling disukai yaitu pada perlakuan D (75\% buah nipah : $25 \%$ rumput laut) dengan skor 3,500\% dan yang kurang disukai pada perlakuan B (25\% buah nipah : $75 \%$ rumput laut) dengan skor $3,450 \%$. Semakin banyak buah nipah ditambahkan maka kesukaan panelis terhadap aroma akan semakin meningkat. Hal ini disebabkan buah nipah memiliki aroma yang khas. Namun setelah pengolahan aroma khas buah nipah cenderung berkurang dan tidak terlalu kuat.

\section{Tekstur}

Tekstur mempunyai peranan penting pada daya terima suatu produk makanan. Uji tekstur adalah penginderaan yang dihubungkan dengan indera perabaan dan sentuhan. Tingkat kekenyalan adalah gaya tekan yang mula-mula menyebabkan deformasi produk baru kemudian memecahkan produk setelah produk tersebut mengalami deformasi bentuk (Soekarto, 1990). 
Penilaian terhadap tekstur dapat berupa kekerasan, elastisitas atau kekenyalan. Parameter pengujian tekstur mengacu pada tingkat kesukaan panelis terhadap kekenyalan (kemudahan sampel untuk digigit).

Tingkat kesukaan panelis terhadap tekstur permen jelly buah nipah berkisar $3,85-3,65 \%$ tekstur yang paling disukai adalah D (75\% buah nipah : $25 \%$ rumput laut) dengan skor $3,85 \%$ dan yang kurang disukai yaitu pada perlakuan A (0\% buah nipah : $100 \%$ rumput laut) dengan skor 3,65\%. Hal ini menunjukkan bahwa semakin banyak jumlah buah nipah yang digunakan dan semakin sedikit rumput laut yang digunakan maka semakin tinggi tingkat kesukaan panelis. Hal ini dikarenakan buah nipah memiliki kandungan air yang cukup tinggi dan rumput laut mengandung karagenan yang dapat meningkatkan kekenyalan pada permen jelly tersebut (Winarno, 1996). Sehingga tekstur dari permen jelly tidak terlalu keras. Selain itu adanya penambahan bahan pembentuk jel yang terlalu banyak akan mengakibatkan permen jelly yang dihasilkan menjadi keras, sedangkan jika terlalu sedikit maka permen jelly yang dihasilkan akan terlalu lembek (Malik, 2010).

\section{KESIMPULAN DAN SARAN}

\section{Kesimpulan}

Berdasarkan hasil penelitian permen jelly buah nipah dan rumput laut bahwa perlakuan terbaik yaitu pada perlakuan D (75\% buah nipah : 25\% rumput laut) dengan skor kadar air $22,00 \%$, kadar gula reduksi $64,66 \%$, kadar pati $22,00 \%$ dan penilaian organoleptik rasa $3,90 \%$, warna $4,20 \%$, aroma $3,50 \%$, tekstur $3,85 \%$.

\section{Saran}

Untuk Penelitian selanjutnya, hendaknya dilakukan upaya untuk menambah daya tahan permen jelly buah nipah (Nypa fruticans wurmb) serta mencari pengenyal lain selain rumput laut dalam pembuatan permen jelly.

\section{DAFTAR PUSTAKA}

Ali S. 1987. Aspek-aspek kimia serta proporsi bahan-bahan pembentuk gel dalam

Pengolahan permen jelly. (SKRIPSI). Bogor. FATETA. IPB.

Alrasyid H. 2011. Pedoman pengolahan Hutan Nipah (Nypa fruticans) Secara Lestari. Puslitbang Human dan Konservasi Alam. Badan Litbang Kehutanan. Departemen Kehutanan. Bogor.

[AOAC]. Assseocation Of Official Analitical Chermis. 2005. Offivial Method Of Analysis (18 Edn). Assoacation Of Official Analytical Chemist Inc. Mayland. USA.

Baharuddin I. Taskirawati. 2009. Hasil Hutan Bukan Kayu. Buku Ajar. Universitas Hasanuddin.

Bandini Y. 1996. Nipah Pemanis Alami Baru. Penebar Swadaya Jakarta.

Buckle K. A. R. A. Edwards, G. H. Fleet, M. Wotton. 1987. Ilmu Pangan, Diterjemahkan Oleh $\mathrm{H}$. Purnomo Dan Adiono. UI Press, Jakarta.

Fardiaz S. 1989. Hidrokoloid. Laboratorium Kimia dan Biokimia Pangan PAU IPB. Bogor.

Fenema Owen. 1996. Food chemistry.T hird edition. Chemical Publishing CompanyInc. New York.

Hambali E. Suryani. Wadli. 2004. Membuat Aneka Olahan Rumput Laut. PT Penebar Swadaya Jakarta. 
Herutami R. 2002. Aplikasi Gelatin tipe A Dalam Pembuatan Permen Jelly Mangga (Mangufera indica L.). \{SKRIPSI\}. Bogor : Fakultas Perikanan dan Ilmu Kelautan. Universitas Bogor.

Hidayat N, Ikariszntiani. K. 2004. Membuat Aneka Olahan Rumput Laut. PT Penebar Swadaya. Jakarta.

Kitamura S. C. Anwar. A. Chaniago, and S. Baba 1997. Handbook Of mangroves in Indonesia : Bali and Lombok. Ministry Of Indonesia and JICA, Jakarta.

Malik. 2010. Permen jelly. http://www.malik.wordpress.com

Diakses pada tanggal 11 Februari 2015.

Minarni. 1996. Mempelajari pembuatan dan penyimpanan permen jelly gelatin dari sari buah kweni [skripsi] Bogor. Fakultas Teknologi Pertanian IPB.

Putri R, M, S, Amin W, Ira. S 2008 penerimaan konsumen dan mutu permen jelly yang diolah dari rumput laut (Eucheuma Cottoni) [Skripsi]. Pekanbaru: Fakultas Perikanan Dan Ilmu Kelautan UNRI.

Ratna, Suwandi S \& Suptijah P 2004. Pengaruh penggunaan air kelapa pada sifat fisiko kimia permen jelly dari (kapphaphycus Alvarezi). [skripsi]. Bogor : Teknologi Hasil Perikanan, fakultas perikanan dan ilmu kelautan IPB.

Thaher M. 2014. Luas Hutan Mangrove. Http://Inhil.

Today.com/2014/Luashutanmangr ove/ [14 februari 2017].
Santoso, D. 2007. Pemanfaatan Rumput Laut Gellidium Sp. Dalam Pembuatan Permen Jelly. Skripsi Program Studi Teknologi Hasil Perikanan, Fakultas Pertanian, Institut Perikanan Dan Ilmu Kelautan, UNRI.

Setyaningsih D. Anton A, Maya P. 2010. Analisis Sensori Untuk Industri Pangan dan Agro. IPB Press. Bogor.

Sudarmadji S. Haryono B \& Suhardi. 1997. Prosedur Analisa Untuk Bahan Makanan Dan Pertanian. Penerbit Liberty. Yogyakarta.

SNI (Standar Nasional Indonesia). 0131440.2005. Gula Kristal Putih. Badan Standarisasi.

SNI (Standar Nasional Indonesia). 3574.2-2008. Mutu Kembang Gula Lunak. Badan Standarisasi Nasional. Jakarta.

Standar Nasional Indonesia 3547. 2. 2008. Revisi Kembang Gula Lunak (Jelly) Departemen Perindustrian.

Soekarto ST. 1985. Penilaian Organoleptik untuk Industri Pangan dan Hasil Pertanian. Bhatara Karya Aksara. Jakarta.

Soekarto ST. 1990. Dasar-dasar Pengawsan dan Standarisasi Mutu Pangan. PAU Pangan dan Gizi IPB. Bogor.

Winarno F G. 2002. Kimia Pangan dan Gizi. PT. Gramedia Pustaka Utama Jakarta

Winarno F. G. 2004. Keamanan Pangan Jilid 1. Bogor: M-Brio Press.

Winarno F. G. 2008. Kimia Pangan Dan Gizi. PT. Gramedia. Jakarta.

WinarnoF G.1996. Teknologi pengolahan laut. Jakarta: Gramedia 